\title{
Flagships of imperialism
}

The PEO company and the politics of empire from its origins to 1867

\section{FREDA HARCOURT}

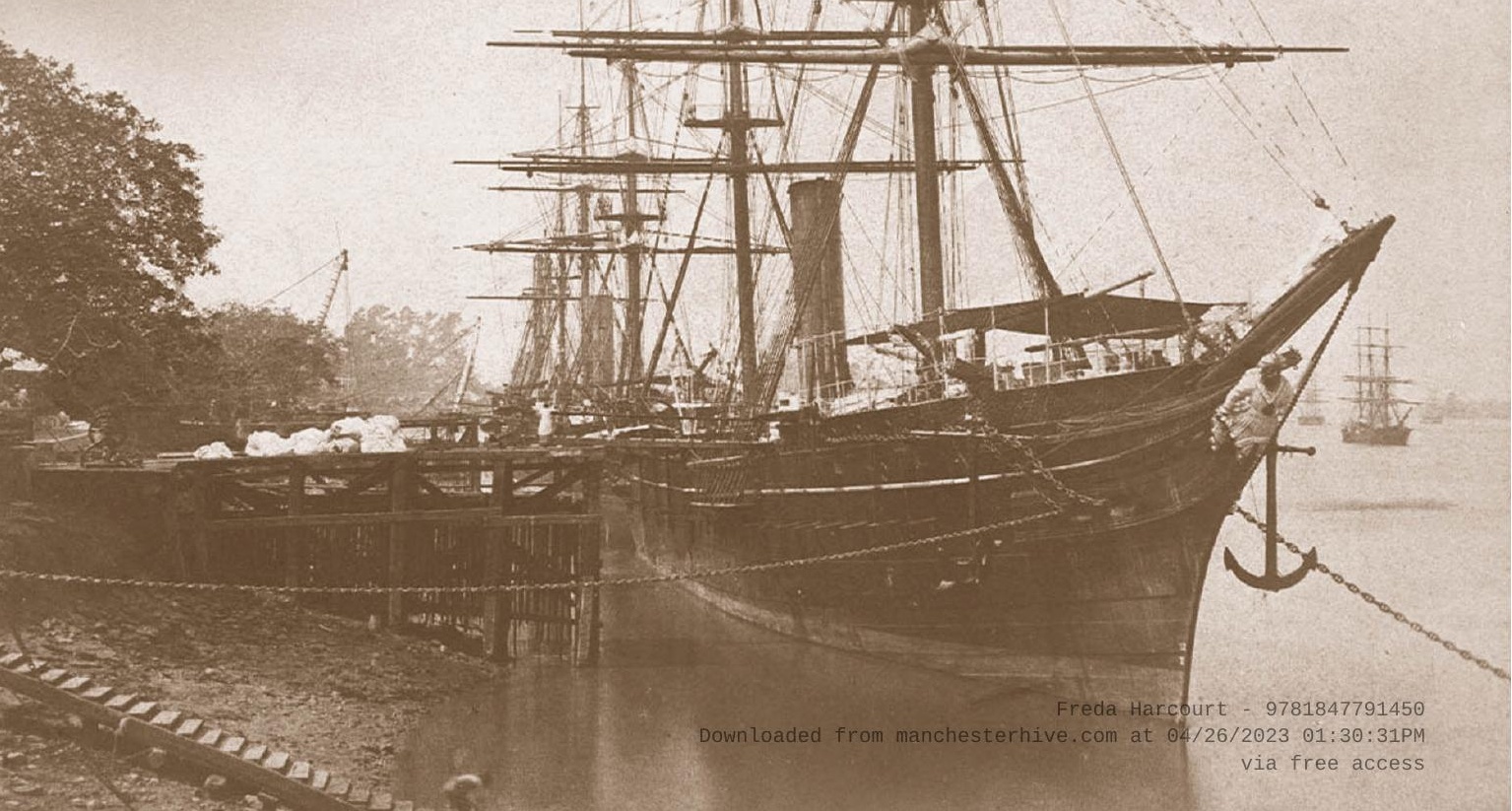




\section{\begin{tabular}{l} 
STUDIES IN- \\
IMPERIALISM \\
\hline
\end{tabular}}

general editor John M. MacKenzie

When the 'Studies in Imperialism' series was founded by Professor John M. MacKenzie more than thirty years ago, emphasis was laid upon the conviction that 'imperialism as a cultural phenomenon had as significant an effect on the dominant as on the subordinate societies'. With well over a hundred titles now published, this remains the prime concern of the series. Cross-disciplinary work has indeed appeared covering the full spectrum of cultural phenomena, as well as examining aspects of gender and sex, frontiers and law, science and the environment, language and literature, migration and patriotic societies, and much else. Moreover, the series has always wished to present comparative work on European and American imperialism, and particularly welcomes the submission of books in these areas. The fascination with imperialism, in all its aspects, shows no sign of abating, and this series will continue to lead the way in encouraging the widest possible range of studies in the field. Studies in Imperialism is fully organic in its development, always seeking to be at the cutting edge, responding to the latest interests of scholars and the needs of this everexpanding area of scholarship.

\section{Flagships of imperialism}

\section{MANCHESTER 1824}

Manchester University Press 


\title{
AVAILABLE IN THE SERIES
}

\author{
CULTURAL IDENTITIES AND THE AESTHETICS OF BRITISHNESS ed. Dana Arnold \\ BRITAIN IN CHINA \\ Community, culture and colonialism, 1900-1949 Robert Bickers \\ NEW FRONTIERS \\ Imperialism's new communities in East Asia, 1842-1952 \\ eds Robert Bickers and Christian Henriot \\ THE ARCTIC IN THE BRITISH IMAGINATION, 1818-1914 \\ Robert G. David \\ IMPERIAL CITIES Landscape, display and identity \\ eds Felix Driver and David Gilbert \\ SCIENCE AND SOCIETY IN SOUTHERN AFRICA ed. Saul Dubow \\ EQUAL SUBJECTS, UNEQUAL RIGHTS \\ Indigenous peoples in British settler colonies, 1830s-1910 \\ Julie Evans, Patricia Grimshaw, David Phillips and Shurlee Swain \\ SCOTLAND, THE CARIBBEAN AND THE ATLANTIC WORLD, 1750-1820 \\ Douglas J. Hamilton \\ EMIGRANT HOMECOMINGS \\ The return movement of emigrants, 1600-2000 Marjory Harper \\ EMPIRE AND SEXUALITY \\ The British experience Ronald Hyam \\ REPORTING THE RAI \\ The British press and India, c. 1880-1922 Chandrika Kaul \\ SILK AND EMPIRE Brenda M. King \\ LAW, HISTORY, COLONIALISM
}

The reach of empire eds Diane Kirkby and Catherine Coleborne COLONIAL CONNECTIONS, 1815-45

Patronage, the information revolution and colonial government Zoë Laidlaw

THE SOUTH AFRICAN WAR REAPPRAISED ed. Donal Lowry

PROPAGANDA AND EMPIRE

The manipulation of British public opinion, 1880-1960 John M. MacKenzie THE OTHER EMPIRE

Metropolis, India and progress in the colonial imagination John Marriott GUARDIANS OF EMPIRE

The armed forces of the colonial powers, c. 1700-1964 eds David Omissi and David Killingray

FEMALE IMPERIALISM AND NATIONAL IDENTITY

Imperial Order Daughters of the Empire Katie Pickles SEX, POLITICS AND EMPIRE

A postcolonial geography Richard Phillips

MARRIED TO THE EMPIRE

Gender, politics and imperialism in India, 1883-1947 Mary A. Procida

IMPERIAL PERSUADERS

Images of Africa and Asia in British advertising Anandi Ramamurthy

IMPERIALISM AND MUSIC Britain, 1876-1953 Jeffrey Richards

THE HAREM, SLAVERY AND BRITISH IMPERIAL CULTURE

Anglo-Muslim relations, 1870-1900 Diane Robinson-Dunn COLONIAL FRONTIERS

Indigenous-European encounters in settler societies ed. Lynette Russell WEST INDIAN INTELLECTUALS IN BRITAIN ed. Bill Schwarz MIGRANT RACES

Empire, identity and K. S. Ranjitsinhji Satadru Sen

THE VICTORIAN SOLDIER IN AFRICA Edward M. Spiers

MARTIAL RACES AND MASCULINITY IN THE BRITISH ARMY, 1857-1914 Heather Streets THE FRENCH EMPIRE BETWEEN THE WARS

Imperialism, politics and society Martin Thomas

BRITISH CULTURE AND THE END OF EMPIRE ed. Stuart Ward 


\section{Flagships of imperialism}

The P\&O company and the politics of empire from its origins to 1867

Freda Harcourt

MANCHESTER UNIVERSITY PRESS

Manchester 
Copyright (C) Freda Harcourt 2006

The right of Freda Harcourt to be identified as the author of this work has been asserted by her in accordance with the Copyright, Designs and Patents Act 1988.

Published by MANCHESTER UNIVERSITY PRESS

ALTRINCHAM STREET, MANCHESTER, M1 7JA, UK

www.manchesteruniversitypress.co.uk

British Library Cataloguing-in-Publication Data

A catalogue record for this book is available from the British Library

Library of Congress Cataloging-in-Publication Data applied for

ISBN 0719073936 hardback

EAN 9780719073939

First published 2006

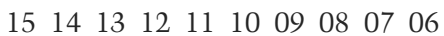

10987654321

The publisher has no responsibility for the persistence or accuracy of URLs for any external or third-party internet websites referred to in this book, and does not guarantee that any content on such websites is, or will remain, accurate or appropriate.

Typeset in Trump Mediaeval

by Graphicraft Limited, Hong Kong 